\title{
Public Organizations Between Old Public Administration, New Public Management and Public Governance: the Case of the Tuscany Region
}

\author{
Nicola Mario Iacovino ${ }^{1} \cdot$ Sara Barsanti $^{1}$. \\ Lino Cinquini ${ }^{1}$
}

Published online: 20 August 2015

(C) The Author(s) 2015. This article is published with open access at Springerlink.com

\begin{abstract}
This paper analyzes the presence of different managerial approaches in a public organization, the Tuscany Region of Italy. In particular, it highlights the phenomenon of the plurality of frameworks working in the organization, namely Old Public Administration (OPA), New Public Management (NPM) and Public Governance (PG). The transformation and coexistence of the above-mentioned models is tested with a content analysis based on the perspectives of policy makers and top-level managers expressed in interviews and on the context of administration planning and control systems found in documents. Each managerial logic has a different relevance in the organization.
\end{abstract}

Keywords Public management $\cdot$ Public administration $\cdot$ New public management $\cdot$ Public governance $\cdot$ Layering process

\section{Introduction}

In recent decades, public organizations have been profoundly transformed, justified by the need to evolve and adapt to the social, economic and political contexts of our postindustrial society. This implies that they are now facing numerous and sometimes conflicting ideas, considerations, demands, structures and cultural elements and, for these reasons, they are becoming increasingly complex and hybrid (Kickert 2001).

Nicola Mario Iacovino

n.iacovino@sssup.it

Sara Barsanti

s.barsanti@sssup.it

Lino Cinquini

1.cinquini@sssup.it

1 Institute of Management, Scuola Superiore Sant'Anna, Piazza Martiri della Libertà, 24-56127 Pisa, Italy 
Moreover, "in a pluralistic society, where there are many criteria for success and different causal understandings, we have to go beyond the idea of a single organizational principle to understand how public organizations work and are reformed and look at them as composite organizations" (Olsen 2007).

This study will explore the evidence of a composite public organization by testing two main hypotheses: $i$. The coexistence of different public managerial logics in the same institution in a certain period; ii. Regarding the theory of Christensen (2010; 2012), Olsen (2010) and Osborne (2006), the existence of a layering process of each model, rather than a linear substitution process from one model to another. The landscape we are referring to is an institution where "some aspects of the OPA have been combined with NPM and PG features to create organizational forms in which governance and management elements coexist with other reform features" (Christensen 2012). In particular, elements of an Old Public Administration (OPA) and/or New Public Management (NPM) and/or Public Governance (PG) will be tested in the case of the Italian Region of Tuscany. It is common knowledge that Italy has always had a "Napoleonic" administrative tradition (Capano 2003; Mussari 1997; Ongaro 2006) and that NPM and PG are unlikely to prevail (Fattore et al. 2012).

Firstly, a conceptual framework based on a literature review of the three different public management models was developed. Then, an explorative qualitative case study to verify the coexistence of different Public Administration models in the same organization at a certain period was conducted. The transformation process and the coexistence of different models were studied by analyzing the perspectives of top-level managers and policy makers in interviews and the context of administration planning and control systems found in documents and regional laws.

\section{Public Administration Models}

Osborne (2006) highlights the fact that "Public Administration and Management" (PAM) has gone through three different leading models: (i) a longer, pre-eminent model, the OPA model, spanning from the late nineteenth century to the late 1970s/ early 1980s; (ii) the NPM model, spanning from the late 1980s to the beginning of the 21 st century and (iii) an emerging model, the PG model. From the 70s, the Public Administrations (hereafter PAs) of western countries have been harshly criticized for self-reference, inefficiency and poor orientation towards customer satisfaction. Since the late 1970s, the majority of developed countries has carried out reforms to modernize and improve the efficiency of their public sector. The most widespread and successful paradigm is the New Public Management (NPM), formulated by Christopher Hood in 1991 (Hood 1991).

The New Public Management comprehends a cluster of theories and studies regarding the modernization of PAs through the introduction of specific management logics belonging to the private sector. The reforms that introduced NPM principles have been carried out in different ways from country to country. In some cases, reforms have focused on increasing the quality of public services for citizens-users and, in some others, they have emphasized the scaling of public equipment (De Vries and Nemec 2013). The main goals were public service quality improvements (Balk 1996), public 
spending savings, more efficient administrations and more effective public policy implementations (Flynn 1993; Frederic 1998; Pollitt and Bouckaert 2000).

In the last decade, however, this model has been criticized and integrated with a new approach, namely the Public Governance (PG) approach (Osborne 2006). This new paradigm aims to overcome the limits of NPM, considered by its critics to be too close to the private sector environment and, in some way, inadequate with regard to the specificities of PA decision-making and management (Monteduro 2005). PG is based on: (i) a general orientation of public sector companies towards the outside (communities and other social and economic public and private actors in the area) rather than the inside; (ii) the importance of the relationship created between subjects belonging to a given socio-economic network and (iii) the ability of the public actor, who usually has the leading role, to manage these relationships (Badia 2007).

\section{Transitions Between OPA, NPM and PG}

When two reform waves, or sets of ideas, like NPM and post-NPM (in our case, PG), meet, there are different mechanisms at work. Christensen (2012) states that there are two different transition hypotheses. The first hypothesis is related to the replacement of different public management models. In this sense, Post-NPM represents a new era of administrative reforms by replacing the former NPM reforms. The hypothesis is often represented as a pendulum swing.

An alternative hypothesis that is closer to our view is the idea of layering, whereby reforms supplement or complement one another in a sort of sedimentation process (Christensen and Lægreid 2010, 2011; Streeck and Thelen 2005). When new reforms are added to old reforms in a layering process, the reform landscape becomes more hybrid and complex. Rather than replacement, we see rebalancing, adjustments, continuities and mixtures of old and new reform features. Mergers and partnerships are installed, but NPM features are not rejected, and traditional bureaucratic forms of specialization and coordination are reintroduced in new versions. We may face coupling, followed by decoupling, and the reintroduction of traditional bureaucratic forms of specialization partly inspired by NPM. NPM cannot be said to be surpassed; rather it has been integrated and improved by the new principles of public governance: «Many NPM- based tools and instruments are still used and optimized in order to support process improvements. Internally governments are still trying to optimize their internal workings. They do this by many different patterns, at least partly diverging from the ideas of NPM, which in itself showed significant shortcomings, although the emphasis therein seems to shift from increased efficiency to improved effectiveness» (De Vries and Nemec 2013). The consequence at an organizational level is the creation of new hybrid organizational forms, in which Old Public Administration has been combined with NPM and post-NPM features (Christensen 2012).

\section{A Matrix for the Comparison of the Different Models}

In order to systematize and compare the key management and governance aspects in each of the three different models (OPA-NPM and PG), a matrix has been proposed. 
The matrix, as described in Table 1, is made up of a set of dimensions of analysis that are intended to highlight the rationale and philosophy of each model, by considering the main variables used by researchers to characterize the models. The framework is mainly inspired by the systematizations of Cepiku (2005), Galdiero (2009), Di Filippo (2005), Monteduro (2005), Rotondo (2011), Sancino (2010), Osborne (2006), Ewalt (2001), Barzelay (1992), Denhardt and Denhardt (2003), O’Flynn (2007), Kooiman and Van Vliet 1993; Mulgan (2000), Shamsul Haque (2000), Hinna (2008), Meneguzzo (2006), Considine (1999, 2001); Considine and Lewis (2003), Padovani et al. (2010). The dimensions consider the focus of each model on the predominant logic, the objectives and workload system, the internal and external relations of the PA, the accountability and planning and control systems orientation, and the organizational and governance models. Although each dimension has fuzzy limits, the matrix captures the value statement and basic assumption of the different models, so that the PA orientation is highlighted.

\section{The Italian Context}

With regard to the implementation of the managerial requalification of PAs, the Italian context lags behind the international cycle (Ongaro et al. 2013). Only since the 1990s, have NPM logics been introduced by Italian law and mainly with a top-down approach: this process has been described as "a process of modernization managed by law" (Di Filippo 2005; Cepiku et al. 2008).

The task of applying these reform logics is far from being accomplished; an "implementation gap" is highlighted in the international and national literature and in public debates on Italy's public administrations and policies (Ongaro and Valotti 2008).

However, this gap is different in the various administrative sectors and regions because local administrations tend to be more creative, receptive and innovative (ibidem, Cepiku et al. 2008).

An analysis of the PA paradigms in a regional context is pertinent because of the continuing decentralization process in Italy. Italian regional administrations have a multifunctional activity, because they have many areas of expertise and there are two simultaneous decision-making levels; a political one and a technical one, with the latter performed by top-level management.

The Case Study The object of this case study is the Tuscany Region. Established as an "Ordinary Statute" region, Tuscany started to operate autonomously in the second half of the 1970s. The region now has about 3,700,000 inhabitants and it is one of the most developed and wealthiest Italian regions (ISTAT 2012). The Statute lays down regional planning as the core process of all regional activities and sets annual and periodical goals.

Tuscany is considered one of the most innovative regions regarding PA management and it is particularly dedicated to NPM (Cinquini and Vainieri 2008; Nuti et al. 2012). In 2011 (the year reviewed here) the regional PA had 2269 employees, 131 of whom were managers. The regional operating structure was composed of a Regional Attorney General, which is autonomous, and five General Directorates (GDs), each responsible for a different sector (Regional Law n. 01/2009). They are responsible for regional 
targets in their areas of expertise and they each have independent accounting, planning and control systems.

\section{Methodology}

Our goal is to verify the presence of a single model or the coexistence of different models (or dimensions of the three models) through an exploratory analysis of a single case study in a specific period of time (Roberts and Bradley 2002). Our final aim is to verify the relation between the three models by testing the substitution or layering process hypothesis (Christensen 2012).

We conducted a content analysis method on (i) semi-structured interviews and (ii) regional laws and documents (listed in the appendix). Interviews were conducted with the general directors of the 5 GDs, the Attorney general and the regional vice-president (the policy-maker). In all, 11 people were interviewed and 20 interview hours were recorded from October to December 2011.

The semi-structured interviews were based on pre-selected themes and the most investigated were: (i) Managing activities and work systems; (ii) Management and control systems, goals assigned to the Directorates; (iii) Organizational performance evaluation systems and (iv) Future expectations for the work system and the evaluation, planning and control systems.

Documents and regional laws were selected by topic. They all refer to rules or regional laws dealing with planning and control issues, and they were issued both by the regional presidency and the single GDs. Table 1 was used as a template to perform a content analysis of the interviews and documents, highlighting the key concepts of each dimension and model.

Content analysis consisted in codifying pieces of writing into various items (or categories) depending on selected criteria (Weber 1922). This approach is used in the literature to carry out qualitative research in accounting, management and governance inside PAs (Fattore et al. 2012; Duriau et al. 2007). Following the content analysis method developed in Fattore et al. (2012), Marcuccio and Steccolini (2009) and Cinquini et al. (2012), a list of key words was identified for each OPA, NPM and PG dimension, in order to help classify relevant expressions (Table 2). We performed a textual analysis, as specified in Table 2, when dimensions did not have key words or when they had similar key words.

In order to enhance the reliability of our content analysis, interviews and documents were analyzed separately and independently by two different coders (the first and second authors), and discrepancies between them were re-examined in collaboration with a third researcher (the third author).

After completing the content analysis, the models were evaluated by counting how often each item appeared in each model, in order to fully understand the respondents' views.

The interview results of both the policy-maker and top-level managers were analyzed with two different perspectives: one concerned their actual experience, which refers to the way they usually run their daily activities, tasks, processes and flows, and one concerned their expectations, which refers to the way they "wish" to run their daily activities, especially concerning performance evaluation and planning systems. 


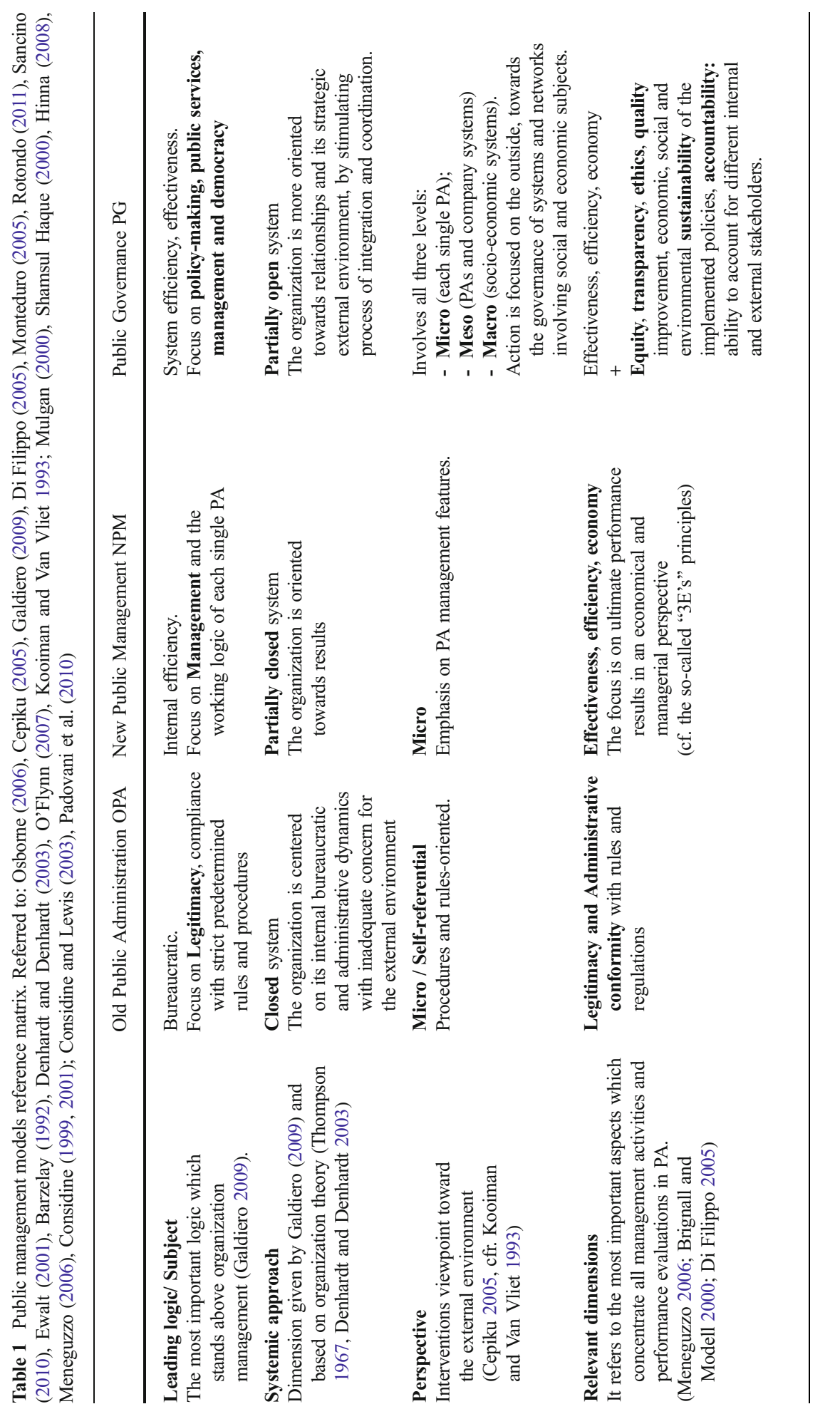




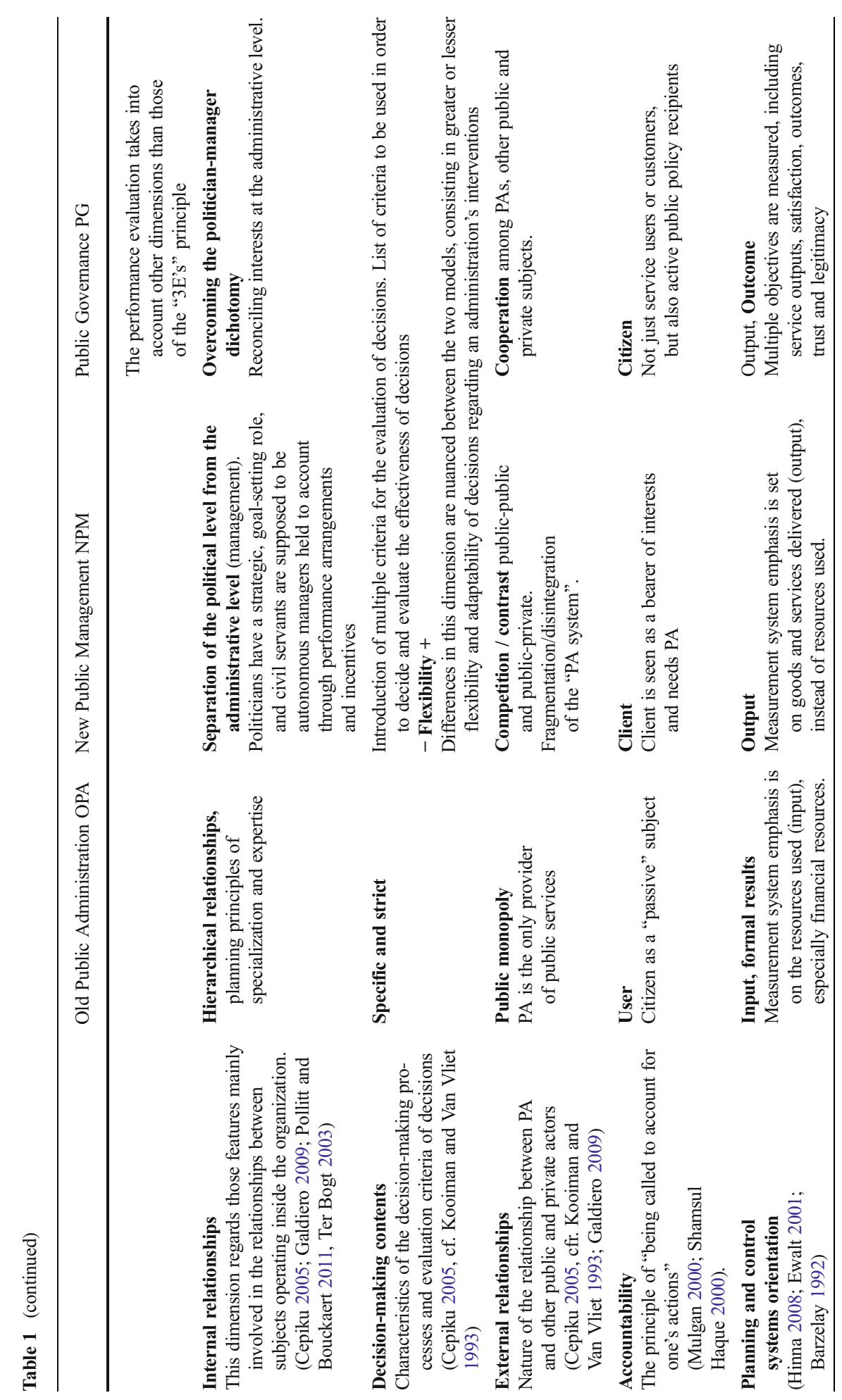




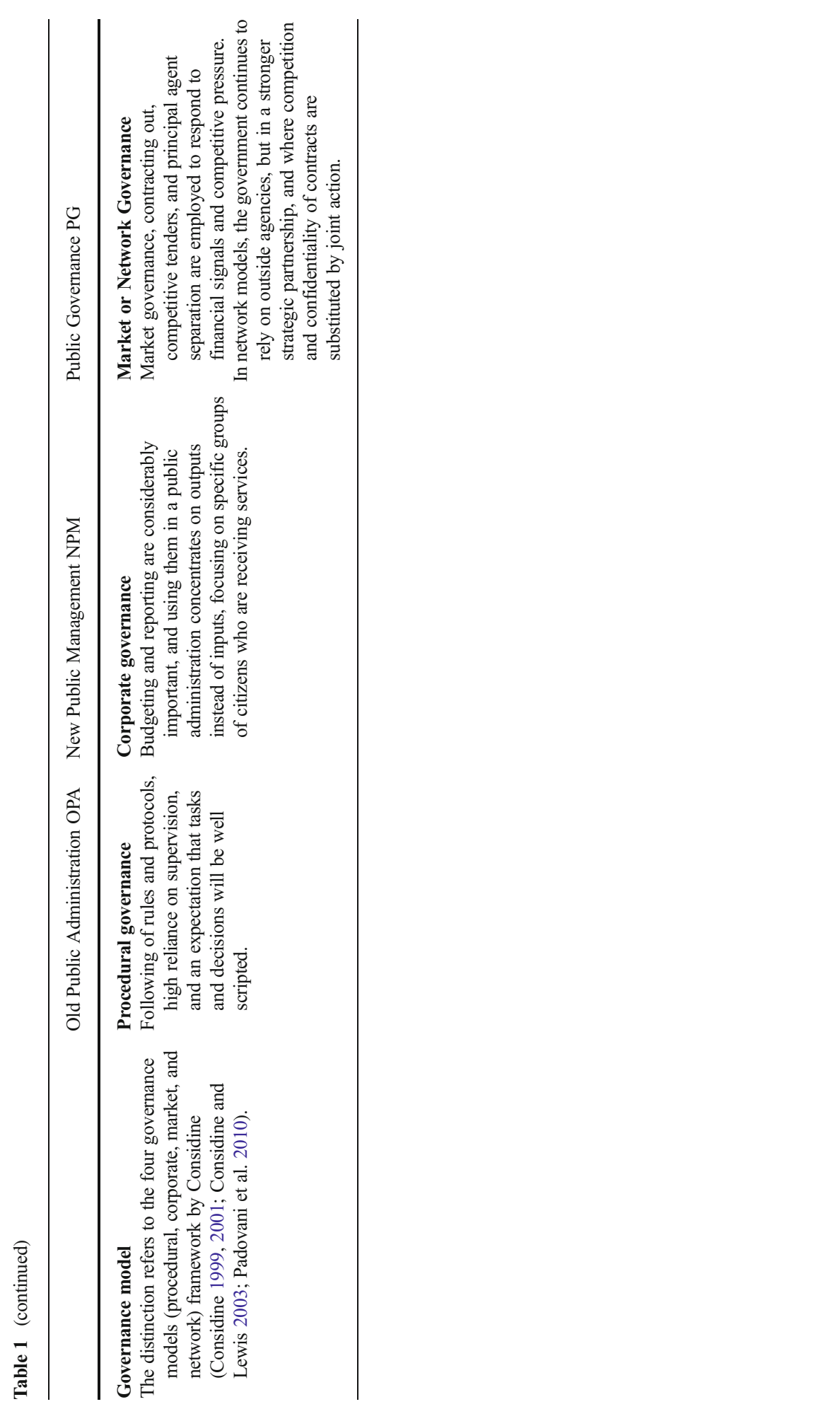




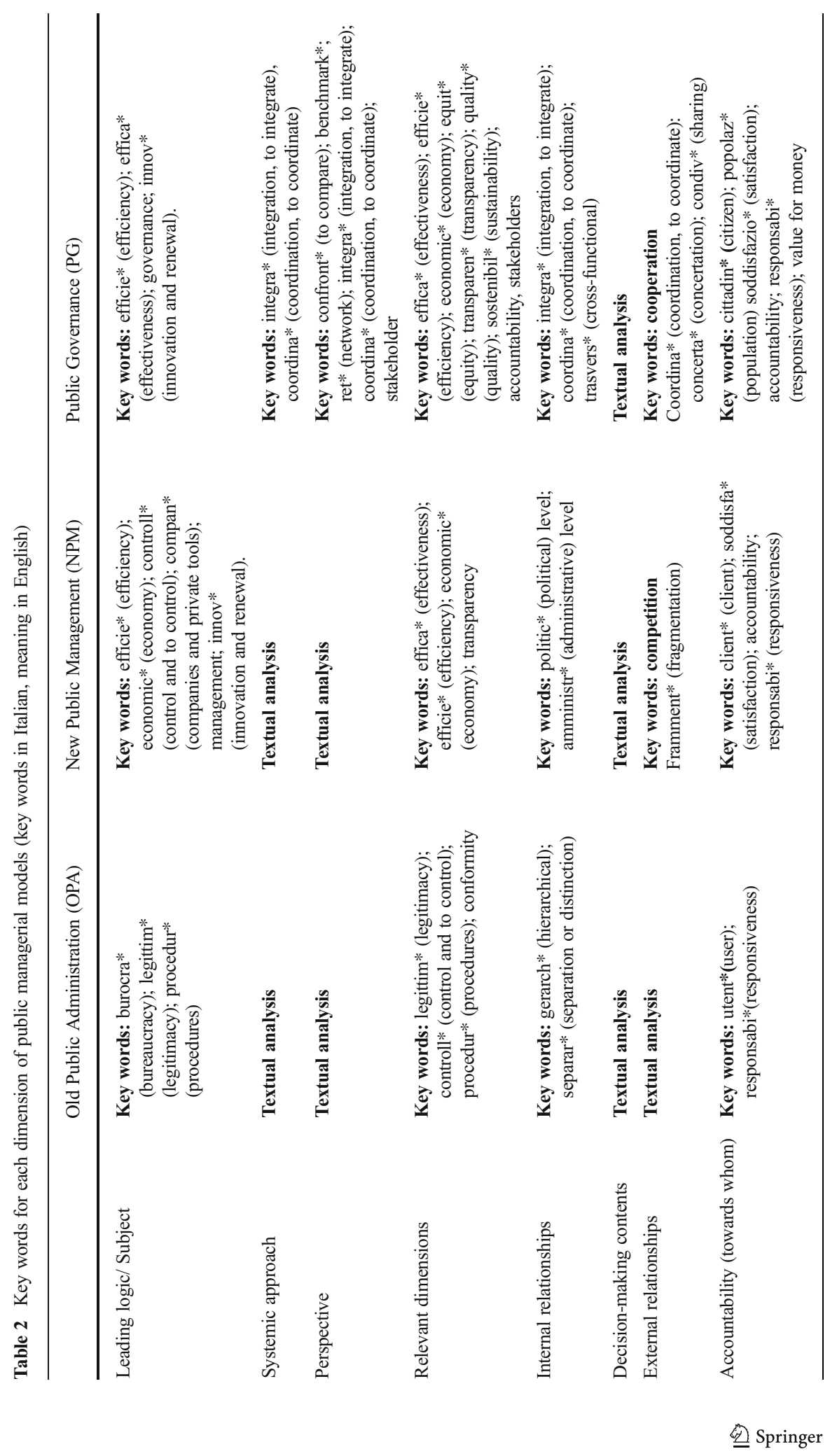




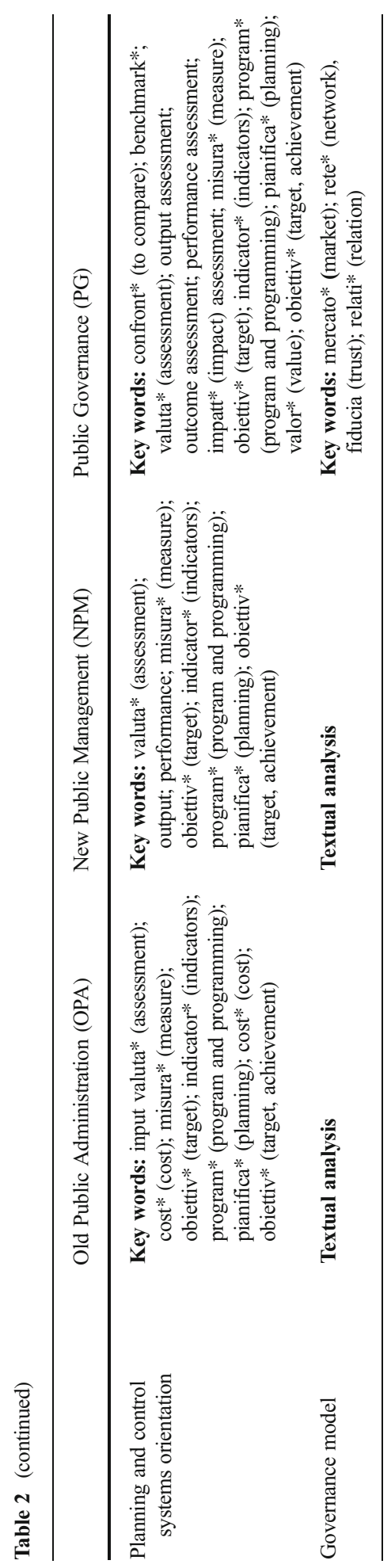




\section{Results}

Table 3 summarizes the results of the content analysis, reporting the frequency of items for each perspective and each managerial model.

The content analysis refers to: (i) Documents and planning laws; (ii) the Policy maker's experience and expectations and (iii) Top management's experience and expectations.

\section{The Strategic Orientation of the Region: The Perspective of Regional Acts and Laws}

As shown in Table 4, regional programming laws and acts appear to be strongly focused on PG logics: $73 \%$ of them (46 out 63) express concepts on aspects of the PG model. The remaining (17 out 63) refer to NPM, and none refer to OPA.

Concepts related to the leading logic of PG are found in 11 cases out of 19 .

This trend is especially highlighted in many parts of the programmatic speeches of the president and in the government program, which underlines the importance of the coordination role of the regional authority over the many different public and private subjects considered as a network, and it is a key element of post-NPM trends (Christensen 2012):

«Tuscany is a "network city" of about 3.7 million inhabitants. While its history and territorial characteristics would encourage us to protect the specificity and diversity of each town municipality, the development and the new concepts of networking and integration encourage us to overcome localism and local peculiarities (...)» (Programmatic speech of the Regional President).

The pursuit of efficiency at a systemic level and of effectiveness in terms of policymaking outcomes seems clear:

«For example, the various regional councilors (the equivalent of ministers in a national government, Ed.) can no longer limit themselves to forming policies;

Table 3 Overall results

\begin{tabular}{lllll}
\hline Object of analysis & $\begin{array}{l}\text { Old public } \\
\text { administration }\end{array}$ & $\begin{array}{l}\text { New public } \\
\text { management }\end{array}$ & $\begin{array}{l}\text { Public } \\
\text { governance }\end{array}$ & Tot. \\
\hline $\begin{array}{l}\text { Regional acts and laws } \\
\text { (the strategic orientation of the Region) }\end{array}$ & - & 17 & 46 & 63 \\
$\begin{array}{l}\text { The policy maker: the vice-president } \\
\text { (experience) }\end{array}$ & 5 & 3 & 7 & 5 \\
$\begin{array}{l}\text { The policy maker: the vice-president } \\
\text { (expectations) }\end{array}$ & - & 2 & 3 & 57 \\
$\begin{array}{l}\text { Top management (experience) } \\
\text { Top management (expectations) }\end{array}$ & 29 & 19 & 9 & 31 \\
Total & - & 17 & 14 & 171 \\
\hline
\end{tabular}


Table 4 The strategic orientation of the region: results of our analysis of regional acts and laws

\begin{tabular}{lllll}
\hline Dimensions & $\begin{array}{l}\text { Old public } \\
\text { administration }\end{array}$ & $\begin{array}{l}\text { New public } \\
\text { management }\end{array}$ & $\begin{array}{l}\text { Public } \\
\text { governance }\end{array}$ & Tot. \\
\hline Leading logic/Subject & - & 8 & 11 & 19 \\
Systemic approach & - & - & 8 & 8 \\
Perspective & - & - & 2 & 2 \\
Relevant dimensions & - & 6 & 4 & 10 \\
Internal relationships & - & - & - & - \\
Decision-making contents & - & - & 3 & 3 \\
External relationships & - & - & 2 & 3 \\
Accountability (towards whom) & - & - & 3 & 10 \\
Planning and control systems' orientation & - & 2 & 8 & 6 \\
Governance model & - & 1 & 5 & 63 \\
Total & - & 17 & 46 & 3 \\
\hline
\end{tabular}

they must also take responsibility for the effectiveness of their interventions, to the extent of their competence». (Government program).

Several references to NPM logics and tools can be found in the same documents as well and they are considered essential for a smooth-running regional machine, such as a "mission budget", a "modern system of analytical controls", and a "system of performance appraisal". They are regarded in PM literature as "efficiency artifacts", i.e. a wide range of instruments employed by managers to solve current problems in public organizations (Vakkuri 2010).

All items regarding system dimensions, perspectives, contents, decisionmaking contents, accountability and external relations are attributable to the PG model. An open-system approach, characterized by integration and coordination logics, emerges in many of the regional laws examined, starting with Regional Law n. 26 of 1992, which regulates, for the first time ever, the regional planning process, focusing, inter alia, on the principles of participation and transparency. The underlying perspective is clearly of the multi-level type, and it integrates the micro, meso and macro dimensions.

Another important dimension that often recurs in the documents on planning is that of the economic and environmental sustainability of policies. It affects the orientation of the planning and control systems towards the PG model. The focus on obtaining results - seen through their impact on citizens - appears clear. Indeed, the Regional Development Program (RDP) includes a set of context indicators and comparisons between Italian regions, in addition to some result indicators on the action plans of the legislature.

\section{The Perspective of the Policy Maker}

The experience and the expectations perceived by the regional vice-president reveal a high prevalence of logics which are consistent with the PG model. As shown in Table 5, 
this happens in 7 out of 15 concepts and almost all of them (5) are related to the internal relations dimension.

The regional vice-president's interview shows how she aims to overcome the politician-manager dichotomy (Pollitt and Bouckaert 2011), and how she balances interests at the administration level through trust, collaboration and flexible relationships.

NPM-related elements stand out in the orientation of the planning and control systems ( 2 concepts out of 3 for the NPM model, and 1 out of 3 for the OPA model) which are mainly based on output indicators to measure targets and activities. However, according to the vice-president, they do not express the whole truth about target achievement:

This year, many indicators were related to output measures. The problem is to understand if these types of measures are sufficient or if, for some of the crossfunctional issues, such as the management efficiency of the administration machine, it is possible to use a "true" indicator, not in terms of output but in terms of outcome, the equivalent of sales.

OPA-related concepts highlight critical issues due to lasting and typically bureaucratic logics, in particular, the lack of cross-functional thinking and flexibility. The vice president underlines the so-called problem of "siloization" (or "pillarization", Christensen 2012):

They still work too much in silos here and this is a serious problem in a public administration where knowledge, even a little knowledge, is power. In this way,

Table 5 The policy maker's perspective

\begin{tabular}{|c|c|c|c|c|c|c|}
\hline \multirow[b]{2}{*}{ Dimensions } & \multicolumn{2}{|c|}{ Old public administration } & \multicolumn{2}{|c|}{ New public management } & \multicolumn{2}{|c|}{ Public governance } \\
\hline & Expectations & Experience & Expectations & Experience & Expectations & Experience \\
\hline Leading logic/Subject & - & 1 & 1 & - & - & 1 \\
\hline Systemic approach & - & - & - & - & - & 1 \\
\hline Perspective & - & 1 & - & - & - & - \\
\hline Relevant dimensions & - & - & - & - & 1 & - \\
\hline Internal relationships & - & - & - & - & - & 5 \\
\hline $\begin{array}{l}\text { Decision-making } \\
\text { contents }\end{array}$ & - & - & - & - & - & - \\
\hline External relationships & - & - & - & - & - & - \\
\hline $\begin{array}{l}\text { Accountability } \\
\text { (Towards whom) }\end{array}$ & - & - & - & - & - & - \\
\hline $\begin{array}{l}\text { Planning and control } \\
\text { systems' orientation }\end{array}$ & - & 1 & - & 2 & 2 & - \\
\hline Governance model & - & 2 & 1 & 1 & - & - \\
\hline Total & - & 5 & 2 & 3 & 3 & 7 \\
\hline
\end{tabular}


you completely lose any cross-functional way of thinking, and managers should work hard to overcome this.

Concerning the expectations of the vice-president, we should consider that, in this case, concepts are rather few (only five). They all belong to NPM and PG, although PG is prevalent for concepts related to planning and control systems orientation (2 out of 2).

\section{The Top-Level Management Perspective}

The daily activities of top-level management are largely dominated by OPA logics, as presented in Table 6. Indeed, as many as $51 \%$ (29 out of 57) of the concepts belong to OPA, $33 \%$ (19 out of 57) to NPM and only $16 \%$ (9 out of 57) to PG.

Instead, top-level management expectations tend to be oriented towards the NPM model (55\% of the concepts, 17 out of 31 ) and, to a lesser extent, to the PG model.

Experience Almost half of OPA-related concepts (12 out of 29) apply to the leading logic which still appears to be bureaucratic in 12 out of the 16 concepts found.

NPM logics seem to have a problem establishing themselves, especially in the planning, reporting and evaluation mechanisms and operations; for example, delays are reported in planning documents, with a negative impact on management activities.

This kind of problem is also evident when there is a lack of differentiation. According to a manager's evaluation:

«Tuscany's regional managers are assessed with scores between 90 and $100 \%$.

Now, even if I aspired to differentiate among them, I would not be able to.

Table 6 Top management's perspective

\begin{tabular}{|c|c|c|c|c|c|c|}
\hline \multirow[b]{2}{*}{ Dimensions } & \multicolumn{2}{|c|}{ Old public administration } & \multicolumn{2}{|c|}{ New public management } & \multicolumn{2}{|c|}{ Public governance } \\
\hline & Expectations & Experience & Expectations & Experience & Expectations & Experience \\
\hline Leading logic/Subject & - & 12 & 6 & 3 & 6 & 1 \\
\hline Systemic approach & - & 2 & - & 1 & - & - \\
\hline Perspective & - & 2 & 1 & - & 1 & 1 \\
\hline Relevant dimensions & - & - & 3 & 3 & 3 & - \\
\hline Internal relationships & - & 2 & 1 & 1 & 1 & 5 \\
\hline $\begin{array}{l}\text { Decision-making } \\
\text { contents }\end{array}$ & - & 2 & 1 & 4 & 1 & 2 \\
\hline External relationships & - & - & - & - & - & - \\
\hline $\begin{array}{l}\text { Accountability } \\
\text { (towards whom) }\end{array}$ & - & - & 1 & 2 & 1 & - \\
\hline $\begin{array}{l}\text { Planning and control } \\
\text { systems' orientation }\end{array}$ & - & 7 & - & 2 & - & - \\
\hline Governance model & - & 2 & 4 & 3 & 4 & - \\
\hline Total & - & 29 & 17 & 19 & 17 & 9 \\
\hline
\end{tabular}


The possibility of giving more realistic assessments, with scores at least between 50 and $100 \%$, also involves a discussion on the targets' system» (GD 1).

Another manager agrees on this aspect:

«There is a problem in setting targets: you should not put year-on-year targets on things that need to be done. Those are not real goals, but fulfillments. The goal has to become the "how" or the overcoming of what I know I must do for competence» (GD 4).

This is confirmed by the experience reported concerning the orientation of the planning and control systems: 7 out of 9 concepts belong to OPA.

These systems and tools do not seem to improve managing activities; indeed, they appear to be partly self-referential and oriented towards the measurement of inputs and formal results. There are some indicators established by law, for example those on the mapping of legislative and administrative activities, but they are not regularly used.

«Mapping processes, considering their expiration and stressing the responsibility of the managers involved are not only elements of good administration, but they are also legal requirements. We are obliged to carry them out because we are responsible towards our citizens and every citizen should be able to know the deadlines for administrative procedures and the persons in charge of each procedure». (GD 2)

Of the nine PG-related concepts, most of them concern internal relationships (5). The relationship between top-level management and policy makers, which should aim to overcome the dichotomy between the two roles (as aforementioned by the vicepresident), is confirmed by the managers interviewed. There is a relationship of trust between policy makers and top-level managers who often have to interact:

«Problems occur when there is a conflict between the area coordinators and the regional councilor or between the general director and the councilor, because it may impair the trust between them and compromise the performance of their activities». (GD 2)

Not a single concept emerged regarding external relationships, which confirm top management's disregard for this issue.

Expectations Most NPM-related concepts (6 out of 17) refer to the leading logic. The managerial innovations discussed in public sector research have not been completely implemented, as already pointed out above. A need to better define objectives and indicators to assess their achievements is strongly felt by top-level managers. Indicators should be better focused on actual priorities, budget management and allocation, and responsiveness to political inputs (including also informal ones):

«This is an important aspect, relating to priorities. In my opinion, the prevailing aspect is to ensure good budget management which is, by nature, a cross-functional activity. Even more important than budget management is the degree of compliance with political inputs that are not written in the stated objectives». (GD 2) 
Most of the expectations of the managers moved to the PG are related to the decisionmaking contents (5 out of 14) and the orientation of the planning and control systems (4 out of 14). The managers expressed the need for greater system flexibility and instrument adaptability to enable the regional administration to face unexpected situations and new challenges posed by external environments, perceived as increasingly discontinuous:

«Another key element is flexibility. Nowadays, strictness, accompanied by a fair amount of flexibility, is essential, together with a strong willingness to change tasks and perspectives». (GD 3)

Adaptation to goals should suit political priorities and contingent activities as much as possible, and it should be carried out in a more timely and flexible way:

«The ability to understand where we stand is critical, so goal adjustment timeliness and achievement measurements are very important. They should also enable us, with the limitations I have represented, to be as close as possible to our political priorities». (GD 3)

As to planning systems, most expectations focused on the importance of setting targets in all the general directorates to improve the results of administrative action:

«Some targets should be cross-functional and they should involve all the general directorates, or at least, the most important ones. Let me add the ability to promote - I think this is an essential point - cross collaboration and cross-functionality». (GD 1)

The corporate model (NPM) dominates expectations about governance. This is clearly stated in two verbatim where respondents discussed the need to map all existing processes as a prerequisite to more virtuous organizational behavior:

«The other problem is networking: once we understand what our colleagues are doing, we can identify redundancies and interactions. This is the right way to improve in the future». (GD 3)

\section{Discussion and Conclusions}

This paper analyzes the current management models of public organizations, such as the Italian Region of Tuscany, with a qualitative approach. Our findings have to be cautiously interpreted due to research limitations. However, they provide a preliminary portrayal of the current logics of public organizations. Figure 1 summarizes the main results by describing the emerging logics for each actor and the documents:

(i) Documents and planning laws mostly embrace PG and NPM logics, as well as political leadership, with a focus on expectations; (ii) the experience of top managers highlights a prevalence of old public administration and partly NPM logics; (iii) GD expectations are more focused on NPM than on PG. Finally, they do not seem to be 
completely aligned with those of top-level policy makers (as seen in the documents and by the vice president's interview).

The different points of view analyzed in our case study highlight two main results.

Hypothesis one: coexistence of different managerial logics in the same PA

Regarding the first hypothesis, we verified that OPA, NPM and PG backgrounds coexist in the same context (in our case, the Tuscany Region) and at the same time (2011). Evidence shows that different parts of the regional PA show a different prevalence of each managerial logic: that is, an OPA background for the experience of top management, a NPM background for policy makers and top management expectations, and a strong PG background found in documents, acts and regional laws. Although Italy has quite a long OPA tradition, this case study of the Tuscany Region shows elements of a transition to innovative public management logics. Nonetheless, the adaptability of a regional PA to the NPM model seems to be quite difficult for both top-level managers and policy makers. Even if the responsibilities of the regional institution are designed as decentralized and managerialized (the General Directorates in the regional administration work as an independent organization with a budget system), this form of organization is still perceived as too bureaucratic and lacking intra-organizational management and cross-functional focus - two typical NPM features (Osborne 2006). The Regional PA is still centered on policy implementation rather than outputs or outcomes. Moreover, the focus of policy implementation is "organizationally distanced" from the policy makers (Osborne 2006).

"Having a lot of sectorial pillars or silos was seen as an obstructing solution of cross-sectorial problems" (Christensen 2012). Even if poor inter and intraorganizational focus and vertical specialization are detected in the experience of policy makers and top managers, horizontal specialization and network governance (both features of PG logic) are considered a more important challenge than vertical specialization. The need to better coordinate a fragmented structure is a typical PG feature, but the process of orienting a regional administration towards the outside world, i.e. towards transparency and participation, is far from being accomplished.

Our results show, in accordance with Christensen (2012) and Olsen (2010), that public administration could present mixed management logics and reforms: "we face a

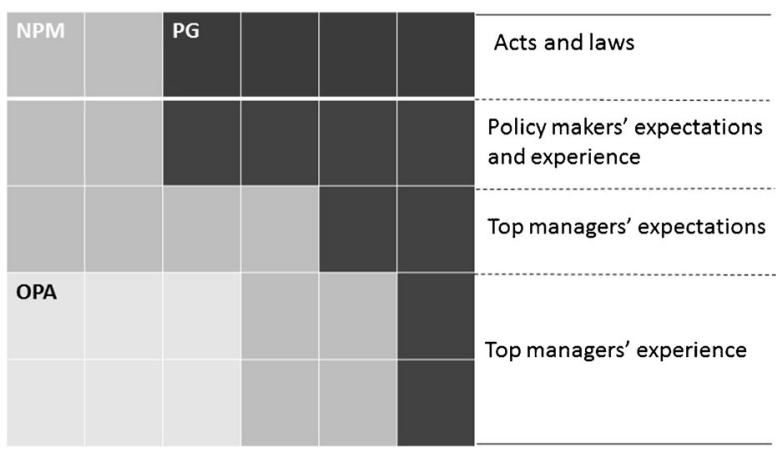

Fig. 1 OPA, NPM and PG as a layering process 
dialectical development in which OPA has been combined with NPM and post NPM (in our case, PG) features to create new hybrid organizational forms" (Christensen 2012).

Hypothesis two: a layering process of culture and reforms

Considering the second hypothesis, new reforms are added to old reforms in a layering process, making the reform landscape more hybrid and complex. The "hybridity" of these organizational forms is caused by a layering process, whereby elements of the different models supplement or complement one another (Christensen and Lægreid 2010; Streeck and Thelen 2005).

In our Tuscany Region case study, NPM or post-NPM reforms are introduced in a culture where there are still prevailing OPA elements such as traditional bureaucratic forms of specialization and coordination. The NPM reform wave, seen as a reaction to the challenges and problems of the 'old public administration', and the post-NPM reform wave, seen partly as a reaction to the negative effects of NPM, have become a complex sedimentation or layering of structural and cultural features (Olsen 2009; Streeck and Thelen 2005). In the course of this process (Røvik 1996), certain elements of structure and culture have appeared relatively stable and coherent (i.e. the "relevant dimension" focused on the same values both in the experience of top managers experience and in documents, see Tables 4 and 6), while others have become stronger or even institutionalized (i.e. the "planning and control system" dimension moving from OPA to PG logic, see Tables 4, 5, and 6), and others have become weakened or deinstitutionalized (i.e. the shift towards a PG logic on the "internal relations" dimension, see Tables 5 and 6). In our case, the layering process is generated both by: $i$. The different experience of top-level managers, policy makers and the values stated by regional acts and laws; ii. The coexistence within the same dimension and the same perspective of the three different managerial logics (see, for example, the "Internal relationships" or "Decision making contents" dimensions for top managers highlighted in Table 6).

figure 1 shows the actual distance between: $i$. the potential diffusion of management tools and culture (i.e. the expectations of top managers) and the expectations of policy makers, which are closer to NPM logics; ii. "an even wider distance" between the mere presence and the actual utilization of management tools (i.e. the experience of top managers) and what is laid down in laws and documents (i.e. the perspective of acts and laws). Ongaro and Valotti (2008) view this as an "implementation gap". This could be due to a resistance to change in Italy's dominant culture (historically a politicized and bureaucratic country), and, consequently, to weak organizational capabilities and poor managerial skills (Valotti 2012), and to a lack of administrative support and innovative tools. This result is also consistent with Panozzo's claim (2000) that although reforms in the Italian public sector tried to introduce managerial logics to the domains of bureaucracy and formal compliance procedures, they were a product of the very culture they were trying to change.

The main limits of our research are related to the use of the content analysis methodology which can create biases due to the lack of independence and/or personal prejudices of the people interviewed, the quantification metric used and the subjective understanding of the issues by the researchers themselves. An ulterior limit may stem from the fact that our research comprises a single-case study in a limited time, which doesn't allow us to generalize our results. 
Finally, further research is needed to carefully investigate this subject by taking into account other variables, such as the individual characteristics of managers, organizational features, and time periods, to better understand management dynamics.

Acknowledgments The authors wish to thank all their colleagues who collaborated on the research project, Professor Andrea Piccaluga, Cristina Campanale, Emilio Passetti, Andrea Tenucci, and all the managers of the Tuscany Region who were interviewed.

\section{Appendix}

Table 7 Regional documents and laws

\begin{tabular}{|c|c|c|c|}
\hline $\begin{array}{l}\text { Title and section analyzed } \\
\text { (in Italian) }\end{array}$ & Type of document & $\begin{array}{l}\text { Year of } \\
\text { approval }\end{array}$ & $\begin{array}{l}\text { Year of } \\
\text { enforcement }\end{array}$ \\
\hline $\begin{array}{l}\text { Toscana 2015. Programma di governo per la IX } \\
\text { Legislatura } \rightarrow \text { Section analyzed: } 4 \text {. } \\
\text { Programmazione e governance della Regione } \\
\text { Toscana;5.1.10 Servizi pubblici locali; } 5.1 .11 \\
\text { Semplificazione amministrativa e rapporti con } \\
\text { gli Enti locali }\end{array}$ & Regional Government Program & 2010 & 2010-2015 \\
\hline $\begin{array}{l}\text { Presentazione del Programma della IX Legislatura } \\
\text { e della Giunta Regionale }\end{array}$ & $\begin{array}{l}\text { Keynote speech of the President } \\
\text { to the Regional Legislative } \\
\text { Council }\end{array}$ & 2010 & $2010-2015$ \\
\hline $\begin{array}{l}\text { Programma Regionale di Sviluppo 2011-2015. } \\
\text { Identità competitiva e sviluppo responsabile } \rightarrow \\
\text { Section analyzed:PIS Semplificazione; } \\
\text { Evoluzione del modello di programmazione, } \\
\text { monitoraggio e controllo }\end{array}$ & $\begin{array}{l}\text { Regional Development } \\
\text { Program (DRP) }\end{array}$ & 2011 & 2011-2015 \\
\hline $\begin{array}{l}\text { La Toscana in chiaro: bilancio sociale } 2011 \\
\rightarrow \text { Section analyzed: Presentazione del Presidente; } \\
\text { Presentazione dell'Assessore al Bilancio }\end{array}$ & Corporate Sustainability Report & 2012 & 2011 \\
\hline $\begin{array}{l}\text { Legge regionale } 17 \text { giugno } 1992, \text { n. 26, Prima } \\
\text { attuazione dell'art. } 48 \text { dello Statuto. (First } \\
\text { implementation of art. } 48 \text { of the Statute) }\end{array}$ & Regional Law & 1992 & \\
\hline $\begin{array}{l}\text { Legge regionale } 11 \text { agosto } 1999, \text { n. } 49 \text {, Norme in } \\
\text { materia di programmazione regionale (Regional } \\
\text { planning regulations) }\end{array}$ & Regional Law & 1999 & \\
\hline $\begin{array}{l}\text { Legge regionale } 2 \text { agosto } 2013 \text {, n. } 44 \text {, Disposizioni } \\
\text { in materia di programmazione regionale } \\
\text { (Regional planning regulations) }\end{array}$ & Regional Law & 2013 & \\
\hline $\begin{array}{l}\text { Legge regionale } 27 \text { dicembre } 2007, \mathrm{n} .69 \text {, Norme } \\
\text { sulla promozione della partecipazione alla } \\
\text { elaborazione delle politiche regionali e locali. } \\
\text { (Law to promote participation in local and } \\
\text { regional policy-making) }\end{array}$ & Regional Law & 2007 & \\
\hline
\end{tabular}


Open Access This article is distributed under the terms of the Creative Commons Attribution 4.0 International License (http://creativecommons.org/licenses/by/4.0/), which permits unrestricted use, distribution, and reproduction in any medium, provided you give appropriate credit to the original author(s) and the source, provide a link to the Creative Commons license, and indicate if changes were made.

\section{References}

Badia, F. (2007). La Public Governance come governo delle relazioni fra diversi soggetti istituzionali su un territorio. Il caso di un'agenzia di ambito territoriale ottimale. Azienda Pubblica, vol. 20, n. 4, ottobre dicembre, pp. 653-673.

Balk, W. L. (1996). Managerial reform and professional empowerment in the public service. Westport: Quorum Books.

Barzelay, M. (1992). Breaking through bureaucracy: A new vision for managing in government. Berkeley: University of California Press.

Brignall, T.J.S., \& Modell, S. (2000). An institutional perspective on performance measurement and management in the 'New Public Sector'. Management Accounting Research, 11 (3).

Capano, G. (2003). Administrative traditions and policy change: when policy paradigms matter: the case of Italian administrative reform during the 1990s. Public Administration, 81(4), 781-801.

Cepiku, D. (2005). Governance: riferimento concettuale o ambiguità terminologica nei processi di innovazione della PA? Azienda Pubblica, 1, 84-110.

Cepiku, D., Meneguzzo, M., \& Senese, M. (2008). Innovations in public management and governance in Italy. Roma: Aracne.

Christensen, T. (2010). Transcending new public management. Økonomi \& Politik, 83(1), s 3-s 13.

Christensen, T. (2012). Post-NPM and changing public governance. Meiji Journal of Political Science and Economics, 1 .

Christensen, T., \& Lægreid, P. (2010). Increased complexity in public sector organizations - the challenges of combining NPM and post-NPM. In P. Lægreid, \& K. Verhoest (ed.), Governance of public sector organizations: proliferation, autonomy and performance. Palgrave Macmillan. Chapter 13. s 255-275.

Christensen, T., \& Lægreid, P. (2011). Complexity and hybrid public administration - theoretical and empirical challenges. Public Organization Review, 11(4), s 407-s 423.

Cinquini, L., \& Vainieri, M. (2008). Measuring primary care services performance: issues and opportunities from a home care pilot experience in the Tuscan health system. Health Services Management Research, 21, 199-210.

Cinquini, L., Passetti, E., Tenucci, A., \& Frey, M. (2012). Analyzing intellectual capital information in sustainability reports: some empirical evidence. Journal of Intellectual Capital, 13(4), 531-561.

Considine, M. (1999). Markets and the new welfare state: employment assistance reforms in Australia. Journal of Social Policy, 28(2), 183-203.

Considine, M. (2001). Enterprising states. The public management of welfare-to-work. Cambridge: University Press.

Considine, M., \& Lewis, J. M. (2003). Bureaucracy, network, or enterprise? Comparing models of governance in Australia, Britain, the Netherlands, and New Zealand. Public Administration Review, 63(2), 131-140.

De Vries, M., \& Nemec, J. (2013). Public sector reform: an overview of recent literature and research on NPM and alternative paths. International Journal of Public Sector Management, 26(1), 4-16.

Denhardt, J. V., \& Denhardt, R. B. (2003). The new public service: Serving not steering. Armonk: M.E. Sharpe.

Di Filippo, E. (2005). I processi di cambiamento nella pubblica amministrazione italiana, http://www.unich.it/ unichieti/ShowBinary/BEA\%20Repository/Area_Siti_federati/Scienze\%20Sociali/Materiale_Didattico/ Materiale\%20didattico\%201112/7\%20FAC\%20SIMILE\%20Tanese $/ 3 \% 20$ Tanese $/ /$ file; jsessionid= KzRwQ3BVh01hkv3Chlq354Q1Jz7ZmrxJ81 VB482jpv6LhpSJStGX!1943790387!307808969.

Duriau, V. J., Reger, R. K., \& Pfarrer, M. D. (2007). A content analysis of the content analysis literature in organisation studies: research themes, data sources, and methodological refinements. Organisational Research Methods, 10(1), 5-8.

Ewalt, J. A. G. (2001). Theories of Governance and New Public Management: Links to understanding welfare policy implementation, paper prepared for presentation at the Annual Conference of the American Society for Public Administration, Newark, NJ. 
Fattore, G., Dubois, H. F. V., \& Lapenta, A. (2012). Measuring new public management and governance in political debate. Public Administration Review, 72(2), 218-227.

Flynn, N. (1993). Public sector management. London: Harvester Wheatsheaf.

Frederic, T. (1998). NPA to NPM: thirty years of progress. Public Administration Times, 21, 1-2.

Galdiero, C. (2009). Il cambiamento istituzionale e la governance dei servizi pubblici: la ricomposizione del campo sanitario italiano alla ricerca di una nuova compliance. In M. Martinez (Ed.), Cambiamento organizzativo e compliance. Assunti teorici e ricerche empiriche. Napoli: Editoriale Scientifica.

Hinna, L. (2008). La misurazione dei risultati nell'ambito dei processi di programmazione, valutazione e controllo delle amministrazioni pubbliche, in Quaderno Formez.

Hood, C. (1991). A public management for all seasons. Public Administration, 69(1), 3-19.

ISTAT (2012). Annuario Statistico Italiano, Roma.

Kickert, W. J. M. (2001). Public management of hybrid organizations: governance of quasi-autonomous executive agencies. International Public Management Journal, 4(2), 135-150.

Kooiman, J., \& van Vliet, M. (1993). Governance and public management. In K. A. Eljassen \& J. Kooiman (Eds.), Managing public organizations: Lessons from contemporary European experience. London: Sage.

Marcuccio, M., \& Steccolini, I. (2009). Patterns of voluntary extended performance reporting in Italian local authorities. International Journal of Public Sector Management, 22(2).

Meneguzzo (2006). Creazione di valore e sviluppo del capitale sociale: la sfida per il sistema della PA italiana, https://doc.rero.ch/record/22482/files/meneguzzo_RIREA_2006.pdf.

Monteduro, F. (2005). La riforma delle amministrazioni pubbliche: Verso la Public Governance. In VV. AA. Nuovi profili di accountability nelle PA: Teoria e strumenti. QUADERNI FORMEZ, vol. 40, ROMA: Formez.

Mulgan, R. (2000). 'Accountability': an ever-expanding concept? Public Administration, 78(3), 555-573.

Mussari, R. (1997). La performance dei servizi pubblici: una sfida culturale, in Luca Anselmi (a cura di) Le aziende degli enti locali tra indirizzo pubblico e mercato (pp. 261-283). Rimini: Maggioli.

Nuti, S., Seghieri, C., \& Vainieri, M. (2012). Assessing the effectiveness of a performance evaluation system in the public health care sector: some novel evidence from the Tuscany Region experience. The Journal of Management and Governance.

O'Flynn, J. (2007). From new public management to public value: paradigmatic change and managerial implications. Australian Journal of Public Administration, 66, 353-366.

Olsen, O. (2007). The ups and downs of bureaucratic organization. The Annual Review of Political Science, $11,13-37$.

Olsen, J. P. (2009). Change and continuity: an institutional approach to institutions of democratic government. European Political Science Review, 1(1), 3-32.

Olsen, J. P. (2010). Governing through institution building. Oxford: Oxford University Press.

Ongaro, E. (2006). The dynamics of devolution processes in legalistic countries: organisational change in the Italian public sector. Public Administration, 84(3), 737-770.

Ongaro, E., \& Valotti, G. (2008). Public management reform in Italy: explaining the implementation gap. International Journal of Public Sector Management, 21 (2), pp.174-204.

Ongaro, E., Ferré, F., Galli, D., \& Longo, F. (2013). Public sector reform in Italy: Views and Experiences from Senior Executives. Country Report as part of the COCOPS Research Project. Coordination for Cohesion in the Public Sector of the Future (COCOPS): www.cocops.eu.

Osborne, S. (2006). The new public governance? Public Management Review, 8(3), 377-387.

Padovani, E., Manes Rossi, F., \& Orelli, R.L. (2010). The use of financial indicators to determine financial health of Italian municipalities, working paper.

Panozzo, F. (2000). Management by decree. Paradoxes in the reform of the Italian public sector. Scandinavian Journal of Management, 16, 357-373.

Pollitt, C., \& Bouckaert, G. (2000). Public management reform: A comparative analysis. New York: Oxford University Press.

Pollitt, C., \& Bouckaert, G. (2011). Public management reform: A comparative analysis - new public management, governance, and the Neo-Weberian state. Press: Oxford Univ.

Roberts, N. C., \& Bradley, R. T. (2002). Research methodology for new public management. International Public Management Journal, 5(1), 17-51.

Rotondo, F. (2011). Principi di public governance nei sistemi integrati di offerta turistica, Giappichelli.

Røvik, K.-A. (1996). Deinstitutionalization and the logic of fashion. In B. Czarniawska \& G. Sev'on (Eds.), Translating organizational change. Berlin: Walter de Gruyter.

Sancino, A. (2010). L'applicazione del paradigma della Public governance negli enti locali: implicazioni per il management, Economia Aziendale Online. 
Shamsul Haque, M. (2000). Significance of accountability under the new approach to public governance. International Review of Administrative Sciences, 66, 599-617.

Streeck, W., \& Thelen, K. (2005). Introduction: Institutional chanage in advanced political economies. In W. Streeck \& K. Thelen (Eds.), Beyond continuity: Explorations in the dynamics of advanced political economies (pp. 1-39). New York: Oxford University Press.

Ter Bogt, H. J. (2003). Performance evaluation styles in governmental organizations: How do professional managers facilitate politicians' work?. Management Accounting Research, 14(4), 311-332.

Thompson, J. D. (1967). Organizations in action. New York: McGraw-Hill.

Vakkuri, J. (2010). Struggling with ambiguity: public managers as users of NPM-oriented management instruments. Public Administration, 88, 999-1024. doi:10.1111/j.1467-9299.2010.01856.x.

Valotti, G. (2012). Public sector reforms: State of the art and future challenges. In Reforming the public sector. Brookings Institutions Press.

Weber, M. (1922) 1978. Economy and society: An outline of interpretive sociology. Berkley, CA: U. California Press.

Nicola Mario Iacovino is a PhD Student at the Institute of Management, Scuola Superiore Sant'Anna of Pisa, Italy. His main current research topics are related to performance evaluation systems in public services.

Sara Barsanti PhD, is an Assistant Professor at the Institute of Management, Scuola Superiore Sant'Anna of Pisa, Italy. Her main current research topics are related to performance evaluation systems in public services.

Lino Cinquini is Professor of Management Accounting and Business Administration at the Institute of Management, Scuola Superiore Sant'Anna of Pisa, Italy. His research areas include cost and performance management and management control in public and private organizations. 